\title{
The Role of Compounds in Graphite Formation in Cast Iron - A Review
}

\author{
Iulian Riposan ${ }^{a^{*}}$, Mihai Chisamera ${ }^{b}$, Stelian Stan ${ }^{c}$ \\ POLITEHNICA University of Bucharest, RO-060042, Bucharest, Romania \\ aiulian.riposan@upb.ro; ${ }^{b}$ mchisamera@hotmail.com; 'constantin.stan@upb.ro
}

Keywords: cast iron, graphite nucleation, grey cast iron, ductile cast iron, solidification, preconditioning, inoculation, inoculation enhancing

\begin{abstract}
The paper reviews original data obtained by the authors, from recent separate publications, specifically concerning graphite formation in the solidification pattern of industrial cast irons, focussing on grey cast iron versus ductile cast iron. Additional unpublished data and selected data from literature are represented in the paper. Complex compounds act as nucleation sites in commercial cast irons, generally in a three-stage graphite formation, but with different sequences: (1) first micro-compound formation is oxide/silicate in grey cast iron and sulphide in ductile cast iron; (2) the second compound nucleates on the first one, as complex manganese sulphide in grey cast iron and complex silicates in ductile cast iron; (3) graphite nucleation on the sides of stage 2 compounds, which have low crystallographic misfit with graphite. Resulphurization $(\mathrm{Mn} / \mathrm{S}$ control), preconditioning with strong oxide forming elements ( $\mathrm{Al}, \mathrm{Zr}$ ), more potent inoculants and inoculation enhancement with $\mathrm{S}, \mathrm{O}$ and oxy-sulphide forming elements were found to be beneficial treatments especially in critical solidification conditions.
\end{abstract}

\section{Introduction}

After iron becomes molten in the melting furnace, superheating causes the liquid cast iron to evolve from a colloidal liquid state, after initial melting, [a Fe-C-Si (Xi) base solution; remnant graphite particles $(0.1$ to $10.0 \mu \mathrm{m})$ and non-metallic inclusions] through to quasi-homogenous up to a quasiideal solution. Only when liquid iron undercools sufficiently $\left(200-230^{\circ} \mathrm{C}\right)$, can the smaller sizes of micro cluster $\left(\mathrm{C}_{6}\right)_{\mathrm{n}}$ exist as stable homogeneous nuclei for graphite particles. [1]

Thermodynamically, the free energy of formation $\left(\Delta \mathrm{G}^{0}{ }_{1723 \mathrm{~K}}, \mathrm{~kJ} / \mathrm{mole} \mathrm{X}\right)$, of oxides/silicates

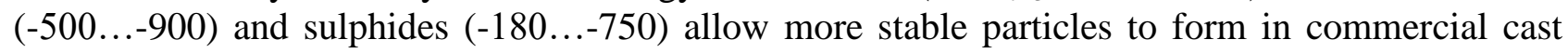
iron melts, than with nitrides $(+100 \ldots-400)$ and carbides $(+10 \ldots-190)$. The specific conditions for these compounds to act as graphite nucleation sites: solid particles; good crystallographic compatibility; low mismatch $\delta(\%)$ between a certain lattice face of some substances and the (0001) face of graphite (Fig 1) [1, 2]; interfacial energy (substrate/graphite) barrier overcoming; fine compounds dispersion $(0.1-10 \mu \mathrm{m}$ generally); lower coagulation capacity; higher thermal stability; optimum level of reactive elements $(\mathrm{O}, \mathrm{S}, \mathrm{N})$ in the melt; easy access to inoculating elements. A possible ranking of nuclei for graphite is as follows: graphite (highest-least energy required), silicates, oxides, sulphides, carbides, nitrides and austenite (lowest). [2-4]

Different graphite nucleation substrates were identified in iron castings. Mn-bearing sulphides were identified to have an important role in graphite formation in grey cast iron while magnesium bearing sulphides, resulting from Mg-treatment of ductile cast iron [5-10], with later validation by more complex and sophisticated analysis system. [11-18] In the same period, other compounds, either simple or complex oxides (silicates) were found and confirmed as graphite nucleants. [5, 8, 9, 15-20] According to Jacobs [8, 9] and Skaland [18], nucleating particles in ductile iron have a duplex structure consisting of a sulphide core $(\mathrm{Mg}, \mathrm{Ca}, \mathrm{S})$ formed during $\mathrm{Mg}$ treatment, surrounded by an oxide/silicate shell, formed during $\mathrm{Mg}$-treatment and inoculation ( $\mathrm{Si}$, $\mathrm{O}, \mathrm{Al}, \mathrm{Ca}, \mathrm{Mg}, \mathrm{Ba}, \mathrm{Sr}$ ). Inoculation can promote complex hexagonal silicate phases on the surface of the previously formed $\mathrm{Mg}$-silicates making them more favourable sites for subsequent graphite nucleation $(\delta<6 \%)$. [18] Simple or complex nitrides/carbo-nitrides also appeared to have a role in graphite nucleation, especially for excessively low sulphur content in the base iron. [19, 21-23] 


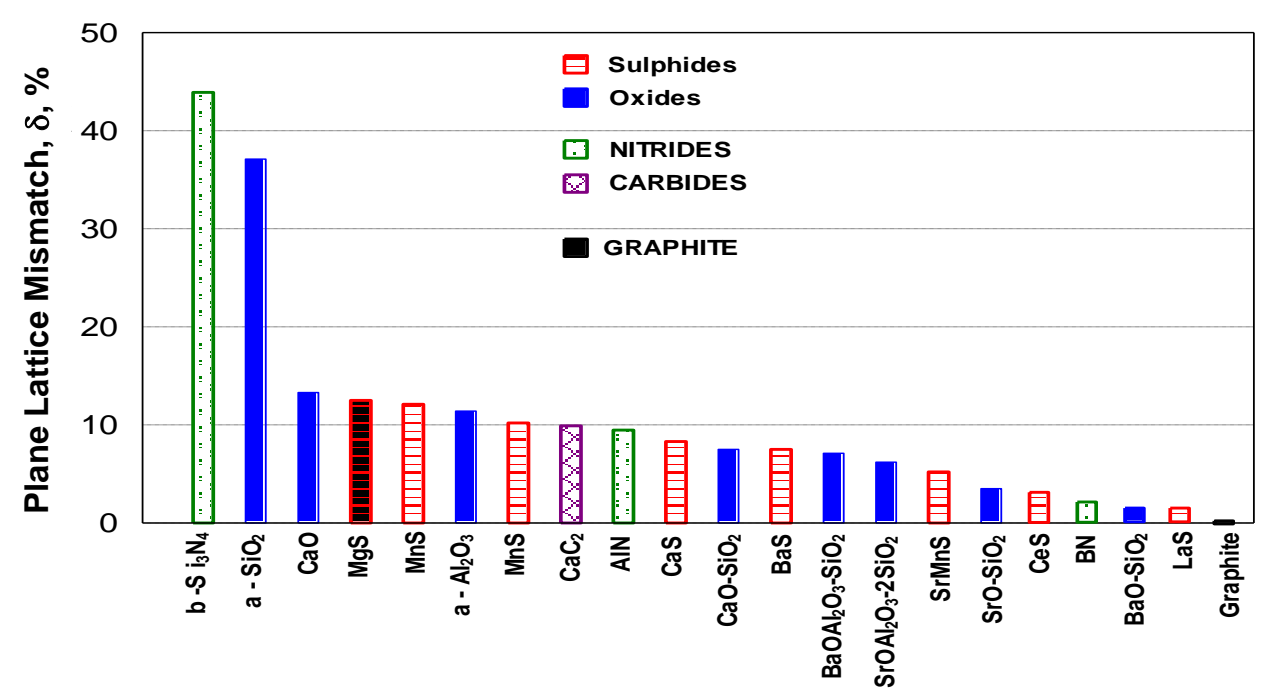

Fig. 1. Mismatch $\delta(\%)$ between a specific lattice face of some substances and the (0001) face of graphite [ $<6 \%$ - strongest, $6-12 \%$ - medium and $>12 \%$ - weak nucleating ability]. [1, 2]

Numerous research studies generated more published data on graphite formation in cast irons, more or less according to the specific experiment conditions, regarding the iron melt and solidification characteristics. Recently [21], a comprehensive work concluded on the "enormous complexity of the study of nucleation of graphite".

The main objective of the present paper was to review original data obtained by the present authors, from recent separate publications, specifically concerning graphite formation in the solidification pattern of industrial cast irons, focussing on grey cast iron versus ductile cast iron. Additional unpublished data and selected data from literature are represented in the paper.

\section{Experimental Procedure}

Table 1 summarizes the selected research programmes with their representative parameters, considered in the present paper, to evaluate the response of different grey cast irons melts $(0.005$ $0.12 \% \mathrm{~S}, 0.2-1.0 \% \mathrm{Mn}, 30-100 \mathrm{ppmO}, 0.001-0.045 \% \mathrm{Al}, 0.002-0.03 \% \mathrm{Ti}, 0.0003-0.013 \% \mathrm{Zr}, 30$ - 100ppm N content), to different FeSi based inoculants and inoculation techniques. More details are included in the previously published reference papers. Experimental cast irons, mainly characterized by carbon equivalent $(\mathrm{CE}=3.5-4.5 \%)$, occupy hypoeutectic - eutectic - slightly hypereutectic positions, with $(\% \mathrm{Mn}) \times(\% \mathrm{~S})=0.002-0.065$ as a control factor. [14] Different techniques were applied to determine the chemical composition, such as spectral (POLYVAC, SPECTROLAB - SPECTRO Spark Analyzer Vision), LECCO (TN15), plasma emission analysis (DCP-Beckman), Baltzers - EXHALOGRAPH 220.

Irons melted in coreless induction furnaces at $1300-1650^{\circ} \mathrm{C}$, were subjected to inoculation, at a large range of inoculant addition rates, by in the mould technique $(0.01-0.3 \mathrm{wt} \%$ alloy) or ladle technique (0.05 - 2.0wt.\% alloy). High Purity (HP)-FeSi alloy was employed as a reference. Different inoculating systems $(\mathrm{Ca} / \mathrm{Sr} / \mathrm{Ca}, \mathrm{Ba} / \mathrm{Ca}, \mathrm{Zr} / \mathrm{Ca}, \mathrm{RE} / \mathrm{Ca}, \mathrm{La})$ were tested, most of them typical of commercial inoculants at: $0.5-1.0 \% \mathrm{Ca} / 0.7-1.0 \% \mathrm{Sr} / 0.75-1.25 \% \mathrm{Ca}+0.75-$ $1.75 \% \mathrm{Ba} / 2 \% \mathrm{Ca}+1.5 \% \mathrm{Zr} / 0.5-1.0 \% \mathrm{Ca}+1.5-2.0 \% \mathrm{RE}$. In some cases special alloys chemistries were designed, in order to test their behaviour in specific conditions: Al content and association with inoculating elements; La use as a rare earth element; $\mathrm{Al}, \mathrm{Ti}, \mathrm{FeSiZr}$ or Al,Zr,Ca-FeSi alloys as preconditioners; oxy-sulphide forming elements alloy ( $\mathrm{S}, \mathrm{O}, \mathrm{Al}, \mathrm{Ca}, \mathrm{Mg}$ and others), alone or with the conventional commercial inoculant.

Experimental data included the characterization of compounds as possible graphite nucleation sites [presence of simple or complex compounds, chemistry and elements distribution on the section, size, shape factors, count etc]. The analysis also referred to cooling curves, chill tendency, graphite size and morphology, carbides occurrence, pearlite / ferrite ratio, eutectic cell 
Table 1. Research programs in the grey cast iron field

\begin{tabular}{|c|c|c|c|c|c|c|c|}
\hline Pr. & Characteristics & $\begin{array}{l}\mathrm{CE} \\
(\%)\end{array}$ & $\begin{array}{c}\mathbf{S} \\
(\%) \\
\mathbf{O}(\mathbf{p p m})\end{array}$ & $\begin{array}{c}\text { Al, Ti, Zr } \\
(\%) \\
\text { N (ppm) }\end{array}$ & $\begin{array}{c}(\% \mathrm{Mn}) \\
\mathbf{x} \\
(\% \mathrm{~S})\end{array}$ & Inoculation & $\mathbf{R}$ \\
\hline I & $\begin{array}{l}* \text { Low \& high } \mathrm{S}, \mathrm{O} \\
* \text { Conventional \& } \\
\text { Overinoculation }\end{array}$ & $\begin{array}{l}3.5- \\
4.0\end{array}$ & $\begin{array}{l}0.005- \\
0.09 \mathrm{~S} \\
30-100 \mathrm{O}\end{array}$ & $\begin{array}{l}0.003-0.01 \mathrm{Al} \\
0.005-0.03 \mathrm{Ti} \\
<0.0005 \mathrm{Zr} \\
30-60 \mathrm{~N}\end{array}$ & $\begin{array}{l}0.002- \\
0.04\end{array}$ & $\begin{array}{l}\text { *Ladle inoculation } \\
* 0.2 \text { wt. } \% \text { and } 2.0 w t . \% \text { alloy } \\
\text { *HP-FeSi; Ca-FeSi; Sr-FeSi }\end{array}$ & $\begin{array}{l}24 \\
25 \\
26 \\
27\end{array}$ \\
\hline II & $\begin{array}{l}\text { *Varied Al content } \\
\text { *High inoculation }\end{array}$ & $\begin{array}{l}3.5- \\
4.4\end{array}$ & $\begin{array}{l}0.07- \\
0.12 \mathrm{~S}\end{array}$ & $\begin{array}{l}0.001-0.045 \mathrm{Al} \\
0.002-0.003 \mathrm{Ti} \\
<0.0005 \mathrm{Zr} \\
30-40 \mathrm{~N}\end{array}$ & $\begin{array}{l}0.035- \\
0.060\end{array}$ & $\begin{array}{l}\text { *Ladle inoculation } \\
\text { *1.0wt.\% alloy } \\
\text { *HP-FeSi; Ca-FeSi (Al); } \\
\text { Sr-FeSi }(\mathrm{Al})\end{array}$ & $\begin{array}{l}27 \\
28 \\
29\end{array}$ \\
\hline III & $\begin{array}{l}\mathrm{Al} / \mathrm{Zr} / \mathrm{Ti} \text { separate } \\
\text { preconditioning }\end{array}$ & $\begin{array}{l}3.7- \\
3.9\end{array}$ & $\begin{array}{l}0.09- \\
0.10 \mathrm{~S}\end{array}$ & $\begin{array}{l}0.002-0.03 \mathrm{Al} \\
0.003-0.017 \mathrm{Ti} \\
0.0005-0.013 \mathrm{Zr} \\
50-60 \mathrm{~N}\end{array}$ & $\begin{array}{l}0.050- \\
0.065\end{array}$ & $\begin{array}{l}* \text { Ladle inoculation } \\
* 0.3 \mathrm{wt} \% \mathrm{Sr}-\mathrm{FeSi}\end{array}$ & $\begin{array}{l}30 \\
31 \\
32 \\
33\end{array}$ \\
\hline IV & $\begin{array}{l}\text { *Low }-\mathrm{S} \text { base iron } \\
\text { *Superheating - } \\
\mathrm{Al} / \mathrm{Zr} \text { variation } \\
\text { *Al,Zr-FeSi prec. }\end{array}$ & $\begin{array}{l}3.9- \\
4.0\end{array}$ & $\begin{array}{l}0.012- \\
0.022 \mathrm{~S}\end{array}$ & $\begin{array}{l}0.003-0.005 \mathrm{Al} \\
0.017-0.018 \mathrm{Ti} \\
<0.0005 \mathrm{Zr} \\
60-80 \mathrm{~N}\end{array}$ & $\begin{array}{l}0.010- \\
0.020\end{array}$ & $\begin{array}{l}* 0.10 \text { wt } \% \text { Al,Zr-FeSi before } \\
\text { tapping } \\
* 0.20 \text { wt. } \% \mathrm{Ca}, \mathrm{Ba}-\mathrm{FeSi} \\
\text { Ladle inoculation }\end{array}$ & 34 \\
\hline $\mathrm{V}$ & $\begin{array}{l}\text { *Low } \mathrm{S} / \mathrm{CE}-\text { iron } \\
\text { *In the mould vs } \\
\text { Ladle inoculation } \\
{ }^{*} \mathrm{Ca}, \mathrm{Zr}, \mathrm{Al} \text { treatm. }\end{array}$ & $\begin{array}{l}3.5- \\
3.6\end{array}$ & $\begin{array}{l}0.025- \\
0.030 \mathrm{~S}\end{array}$ & $\begin{array}{l}0.002-0.003 \mathrm{Al} \\
0.005-0.007 \mathrm{Ti} \\
<0.0005 \mathrm{Zr}\end{array}$ & $\begin{array}{l}0.012- \\
0.015\end{array}$ & $\begin{array}{l}* \text { In the mould / Ladle } \\
\text { inoculation } \\
* 0.05-0.25 \mathrm{wt} \% \text { alloy } \\
* \mathrm{Ca}, \mathrm{Zr}, \mathrm{Al}-\mathrm{FeSi} \text { Inoculant }\end{array}$ & 35 \\
\hline VI & $\begin{array}{l}\text { *Low } \mathrm{S} \text { base iron } \\
* \text { La inoculation }\end{array}$ & $\begin{array}{l}3.6- \\
3.8\end{array}$ & $\begin{array}{l}0.025- \\
0.030 \mathrm{~S}\end{array}$ & $\begin{array}{l}0.003 \mathrm{Al} \\
0.005 \mathrm{Ti} \\
<0.0005 \mathrm{Zr}\end{array}$ & $\begin{array}{l}0.015- \\
0.020\end{array}$ & $\begin{array}{l}\text { *Ladle inoculation } \\
* 0.15 \text { wt.\% La,Ca-FeSi }\end{array}$ & 36 \\
\hline VII & $\begin{array}{l}\text { *Low S base iron } \\
* \text { Complex oxy- } \\
\text { sulphide forming } \\
\text { elements inoculant }\end{array}$ & $\begin{array}{l}3.9- \\
4.0\end{array}$ & $\begin{array}{l}0.020- \\
0.025 \mathrm{~S}\end{array}$ & $\begin{array}{l}<0.005 \mathrm{Al} \\
<0.01 \mathrm{Ti} \\
<0.0005 \mathrm{Zr} \\
<100 \mathrm{~N}\end{array}$ & $\begin{array}{l}0.015- \\
0.020\end{array}$ & $\begin{array}{l}\text { *In the mould inoculation } \\
* 0.01-0.03 \text { wt. } \% \text { alloy } \\
* 0.1-0.3 \text { wt. } \% \text { FeSi } 75\end{array}$ & 37 \\
\hline VIII & $\begin{array}{l}\text { *Low S base iron } \\
\text { *Inoculation } \\
\text { enhancing by oxy- } \\
\text { sulphide forming } \\
\text { elements addition } \\
\end{array}$ & $\begin{array}{l}3.7- \\
3.9\end{array}$ & $\begin{array}{l}0.03- \\
0.04 \mathrm{~S}\end{array}$ & $\begin{array}{l}0.0019- \\
0.0022 \mathrm{Al} \\
0.008-0.0094 \mathrm{Ti} \\
<0.0006 \mathrm{Zr} \\
50-100 \mathrm{~N}\end{array}$ & $\begin{array}{l}0.013- \\
0.016\end{array}$ & $\begin{array}{l}\text { *In-Mould inoculation } \\
\text { *0.10\%wt.\% Ca-FeSi / } \\
\text { Ca,Ba-FeSi / CaRE-FeSi } \\
\text { *0.03wt.\% Inoculant + } \\
0.01 \text { wt.\% Enhancer }\end{array}$ & 38 \\
\hline IX & $\begin{array}{l}* \text { Fe-powder } \\
\text { treatment }\end{array}$ & $\begin{array}{l}4.3- \\
4.5\end{array}$ & $\begin{array}{l}0.03- \\
0.04 \mathrm{~S}\end{array}$ & $\begin{array}{l}0.0015- \\
0.0025 \mathrm{Al}\end{array}$ & $\begin{array}{l}0.015- \\
0.020\end{array}$ & $\begin{array}{l}* 1.0 \text { wt. } \% \text { Fe-powder } \\
* 0.2 \text { wt. } \% \text { Ca,Ba,Al-FeSi }\end{array}$ & $\begin{array}{l}40 \\
41 \\
42 \\
\end{array}$ \\
\hline
\end{tabular}

count, mechanical properties etc, in different associations, typically for each experimental programme. The present paper focused on characterization of the graphite nucleation sites, with results (factors) selected for their strong effects influencing grey cast iron quality. Three different analysis techniques (SEM, TEM, EPMA) were applied to estimate the role of found compounds.

\section{Results and Discussion}

The higher the inoculating element content in the inoculant, the higher the residual content in the cast iron. For greater inoculant additions there was a higher content of these elements in the final irons, for all levels of inoculating elements in the treatment alloys (Fig. 2). Figure 3a illustrates a typical compound acting as a nucleation site for lamellar graphite, in comparison to nodular/spheroidal graphite formation (Fig. 3b). Such compounds at the micron size level $(0.1-$ $10 \mu \mathrm{m}$ generally, mainly $<5.0 \mu \mathrm{m}$ ) (Fig. 5) were found in different positions in the grey cast iron structure (Fig. 4a): (1) no connection with graphite [embedded in the metal matrix]; (2) superficial contact with graphite; (3) partial and (4) fully encapsulated by graphite. The majority of these particles present a clear core (nucleus) at $0.1-2.7 \mu \mathrm{m}$ size $(0.4-2.0 \mu \mathrm{m}$ prevalent average). Generally, smaller sized compounds, the higher their capacity to act as graphite nucleation sites, but many other influencing factors could be critical. The compounds fully encapsulated in graphite in 


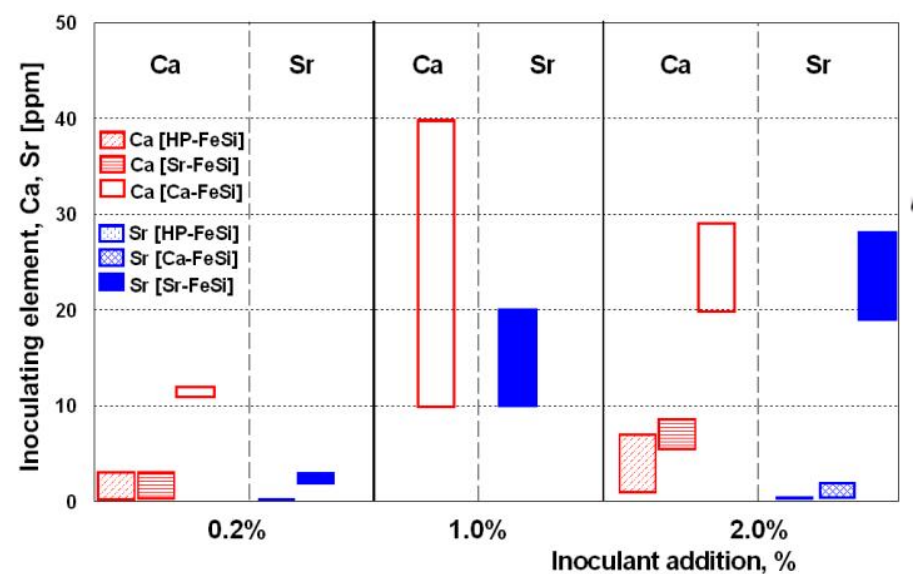

Fig. 2. Final content of $\mathrm{Ca}$ and $\mathrm{Sr}$ in inoculated grey cast irons [Programmes I and II]

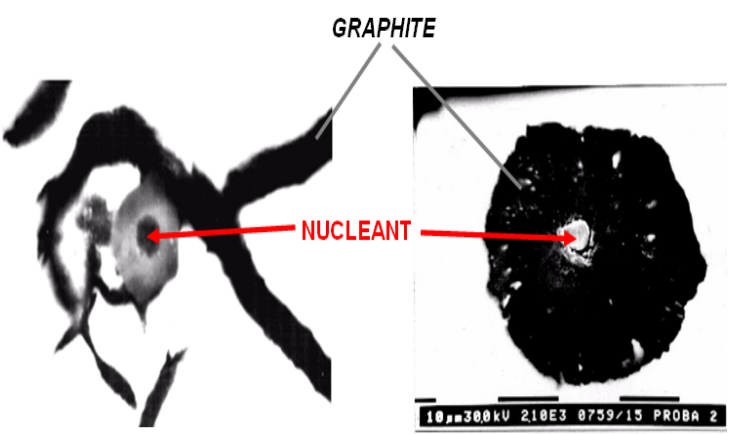

(b)

Fig. 3. Graphite nucleation in grey (a) [24] and ductile (b) cast iron [39]

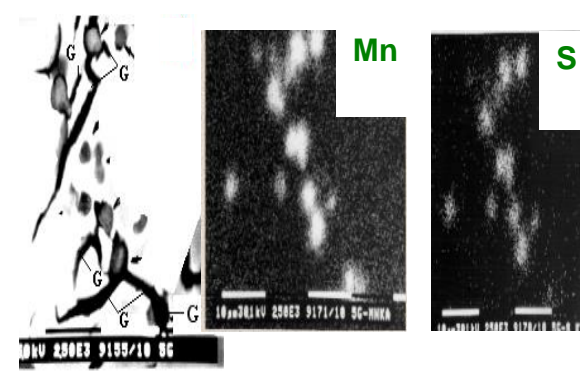

(a)

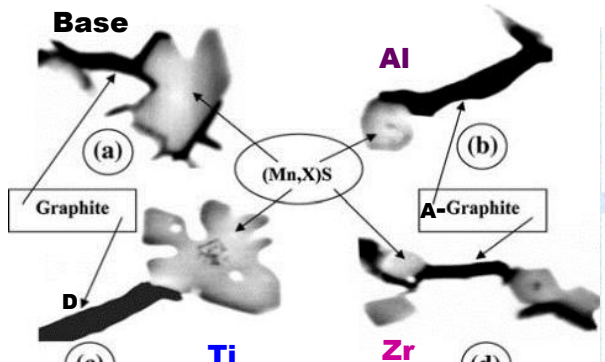

(c) $\quad \mathrm{Ti}$ (d)

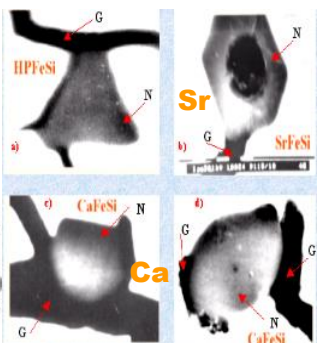

(c) (b)

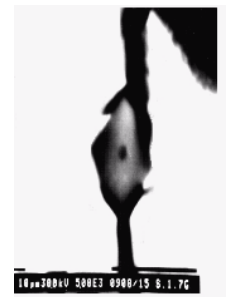

(d)

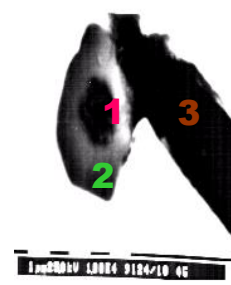

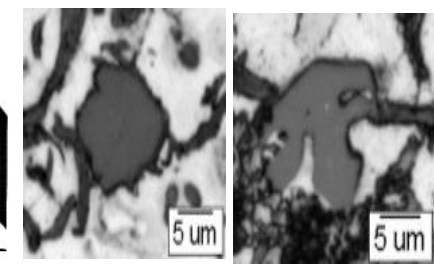

(e)

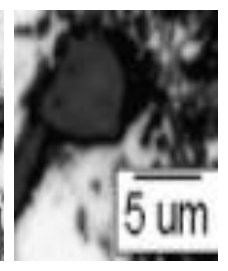

(f)

(g)

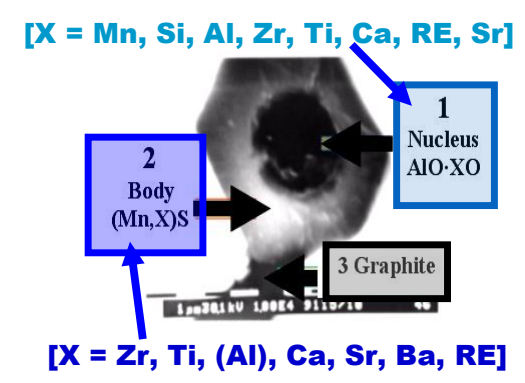

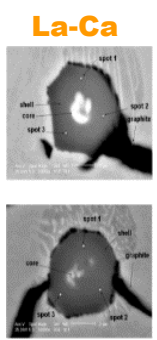

(h)

Fig. 4. Typical compounds as graphite nuclei in different grey cast irons [(a) compounds and Mn, S distribution; (b) Al, Ti, Zr preconditioning; (c, d) Ca, Sr, La inoculation; un-treated (e), Fe-powder (f) and Fe-powder and inoculation treatment (g); (h) three stage lamellar graphite nucleation model]

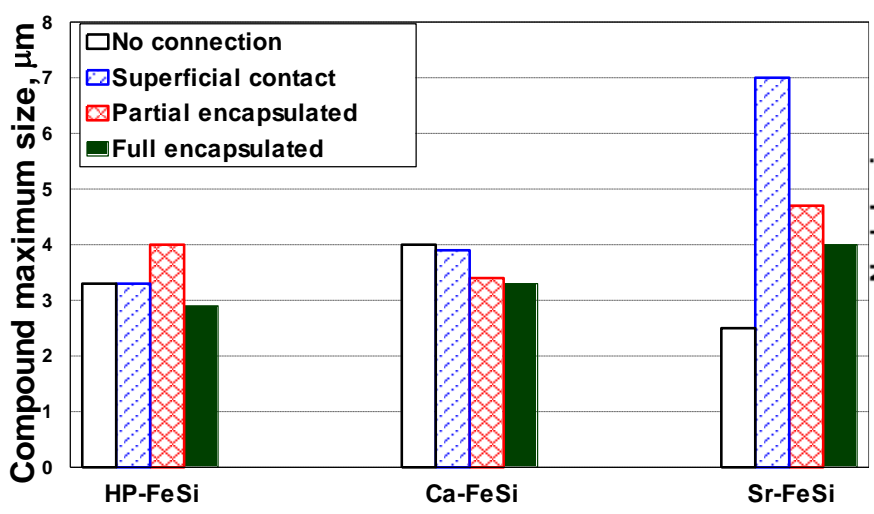

(a)

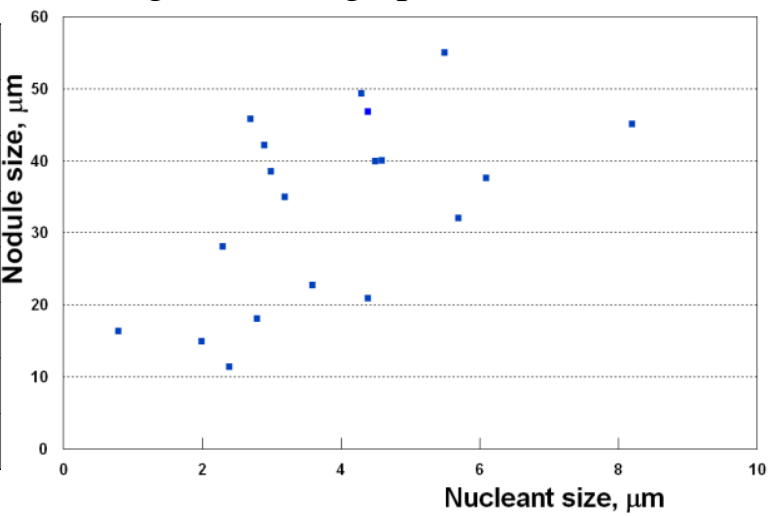

(b)

Fig. 5. Compounds maximum size, at different positions in the grey cast irons structure (a) and nodule size - nucleant size relationship in ductile irons (b) 
grey cast iron are characterized by the lowest average size (Fig. 5a). [24, 26], Also in ductile irons, the lower nucleant size results in lower graphite nodule size, (Fig. 5b). [39] The size of principal compounds mainly depends on the iron cooling rate (higher cooling rate, lower size compound) and inoculant type: the compound size continues to decrease from un-inoculated to HP-FeSi and $\mathrm{Sr}-\mathrm{FeSi}$ treated irons and especially to $\mathrm{Ca}-\mathrm{FeSi}$ treated irons. The morphology of compounds are mainly ovoid shaped in the $\mathrm{Ca}-\mathrm{FeSi}$ treated iron, a regular polygonal shape in $\mathrm{Sr}-\mathrm{FeSi}$ and $\mathrm{Ca}, \mathrm{La}-\mathrm{FeSi}$ treated irons and predominantly irregular polygonal shape in the HP-FeSi treated iron.

In the oxide forming elements preconditioning programme III [Table 1], the graphite nucleants average size $[\mu \mathrm{m}]$ was clearly dependant on the preconditioning agent: Reference: $\mathrm{Ti}: \mathrm{Al}: \mathrm{Zr}=7.8: 9.1: 4.8: 3.4$. A high population of small particles with a quasi-regular polygonal shape, favourable for type A graphite nucleation, typically occur after $\mathrm{Al}$ and $\mathrm{Zr}$ preconditioning [see Fig. 4b - (b), (d)]. Larger particles with a lower numerical count and an outline mainly indented, like a dendrite, favour type $\mathrm{D}$ graphite formation, thereby characterizing $\mathrm{Ti}$ preconditioned irons [see Fig. 4b - (c)]. Type D graphite formation tendency in the presence of $\mathrm{Ti}$ could be explained by this effect on the graphite nucleant morphology.

Research programme IX [Table 1] evaluated the effects of Fe-powder additions on the structure of slightly hypereutectic grey cast irons $(\mathrm{CE}=4.3-4.5 \%)$. It was found that Fe-powder additions favour austenite dendrite formation, acting as reinforcement for eutectic cells, but the treatment led to the largest particles with unsuitable morphologies for the development of graphite nuclei (see Fig. 4f vs Fig. 4e). It was confirmed that compact micro-inclusions (Fig. 4g), promoted by inoculation after Fe-powder addition, because of their smaller size, made them more active in graphite nucleation, lowering the irons chill sensitivity with improved eutectic cell characteristics.

In all the recorded research programmes (see Table 1), $(\mathrm{Mn}, \mathrm{X}) \mathrm{S}$ compounds (where $\mathrm{X}=\mathrm{Fe}$, $\mathrm{Al}, \mathrm{O}, \mathrm{Si}, \mathrm{Ca}, \mathrm{Sr}, \mathrm{Ti}, \mathrm{Zr}, \mathrm{Ce}, \mathrm{La}, \mathrm{Ba}, \mathrm{P}$ etc) were found as major sites for graphite nucleation in grey cast irons. More than $0.04 \% \mathrm{~S}$ content appears to favour manganese sulphide formation, with apparent difficulty if the sulphur content is less than this, especially less than $0.02 \% \mathrm{~S}$. The two identifiable parts of the compounds are found to have different chemical compositions (Fig. 6): the first one, an oxide/silicate acts as a nucleation site for the second one, a sulphide type, and contributes to graphite formation. The hypothesis is that oxides are first to form as stable microcompounds in the iron melt and become a more effective nucleation site for graphite by the additional complex manganese sulphides, similar to steel melt solidification. [43-45]

Higher $\mathrm{Al}$ content in the melt led to a detectable $\mathrm{Al}$ increase in the core of graphite nucleant, but only a lesser increase in the shell (Fig. 7), so Al has a vital role mainly in the first stage of graphite nucleation (early oxide-based micro-inclusions). $\mathrm{Zr}$ appears to have a similar role to $\mathrm{Al}$ and more so for graphite nucleation, i.e it has a double role: (1) early $\mathrm{Zr}$-oxide based micro-inclusions to sustain $(\mathrm{Mn}, \mathrm{X}) \mathrm{S}$ compound nucleation and (2) improving the structure of $(\mathrm{Mn}, \mathrm{X}) \mathrm{S}$ compounds to increase their capacity to nucleate flake graphite, at less undercooling. It appears that Mn would be replaced by $\mathrm{Si}$, which was replaced by $\mathrm{Al}$, possible replaced by $\mathrm{Zr}$, in formation of the first compound according to their potential to form oxides. Generally, Ti was present in the graphite nucleants with and without $\mathrm{Ti}$ addition $(0.003-0.008 \% \mathrm{Ti}$ residual), with an inhomogeneous distribution in the shell.

$\mathrm{Ca}$ is present in the most compounds, in all test irons, with maximum level in $\mathrm{Ca}-\mathrm{FeSi}$ treated irons. Ca appears to be similarly distributed in the shell and core, with a $\mathrm{Ca}[$ shell] / $\mathrm{Ca}$ [core] ratio of $0.5: 1.0$. Sr was found mainly in the core of the nuclei of graphite but only if the irons had been inoculated with a $\mathrm{Sr}-\mathrm{FeSi}$ alloy. When $\mathrm{Al}$ or $\mathrm{Zr}$ was added, $\mathrm{Sr}$ and Ca levels increased in the shell of $(\mathrm{Mn}, \mathrm{X}) \mathrm{S}$ compounds. This was also associated with improved graphite nucleation performance with less eutectic undercooling. La appears to form inclusions later than Al, since the La-rich phase surrounds an Al-rich phase and confirms the key-role of $\mathrm{Al}$ in the first stage. the presence of both $\mathrm{La}$ and $\mathrm{Ca}$ in the shell of the $(\mathrm{Mn}, \mathrm{X}) \mathrm{S}$ make these inclusions better nucleation sites for graphite. The role of $\mathrm{La}$ with $\mathrm{Ca}$ and $\mathrm{Al}$ seems to be dual purpose assisting with the formation of the early particles and then further modifies the newly created particles to become effective nucleation sites for the ultimate target - graphite. 


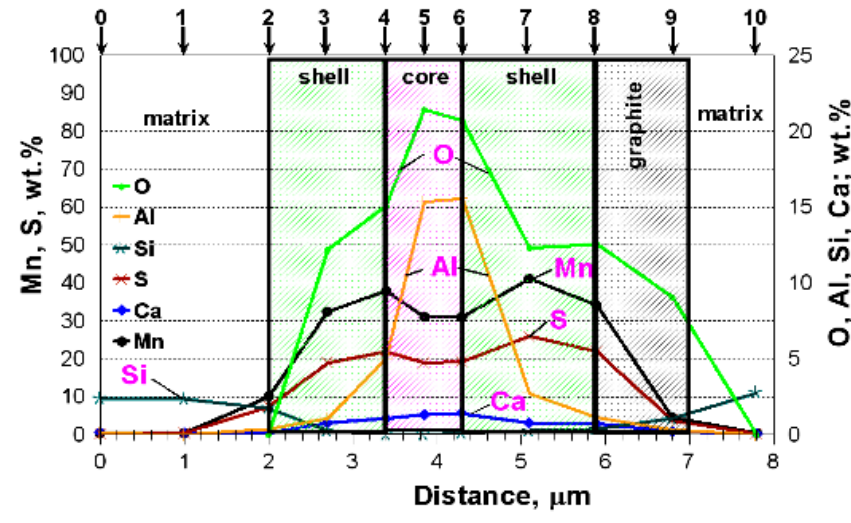

(a)

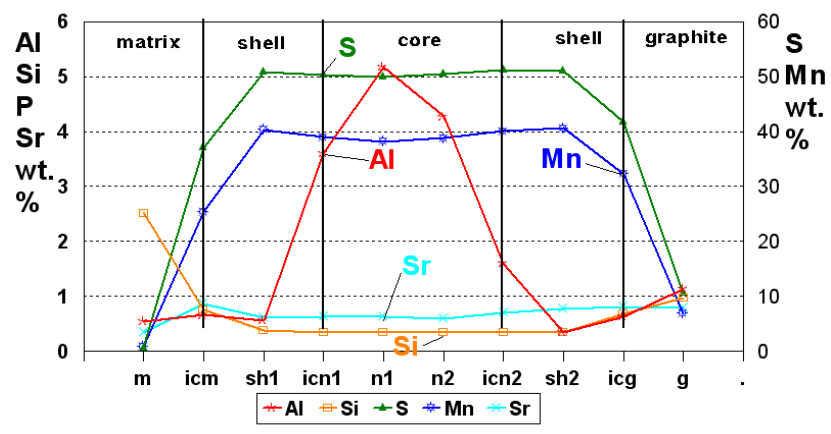

(c)

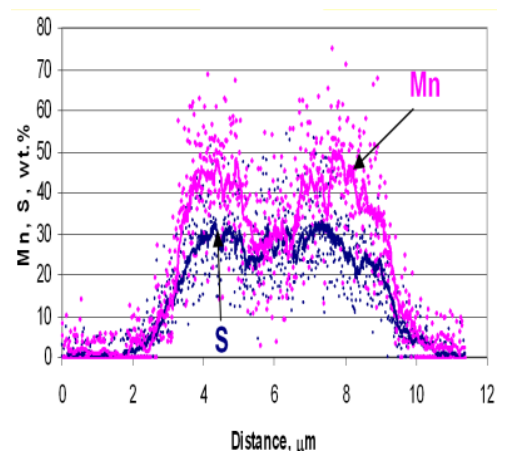

(e)

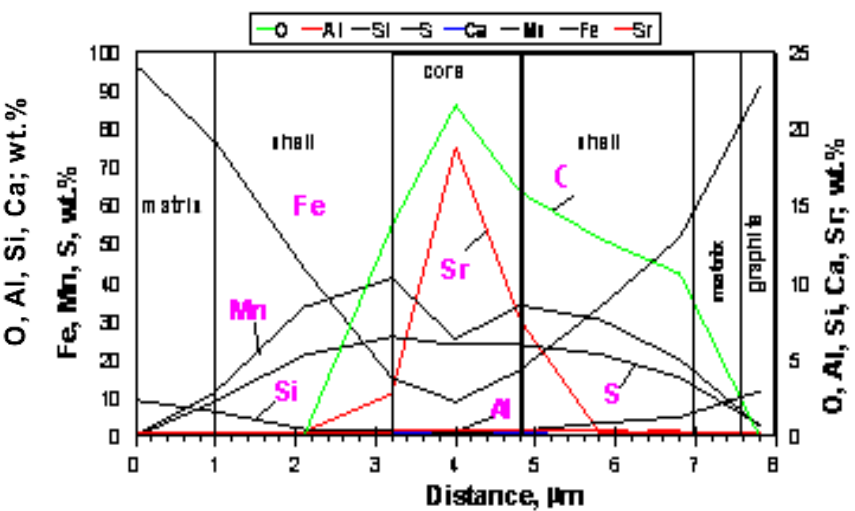

(b)

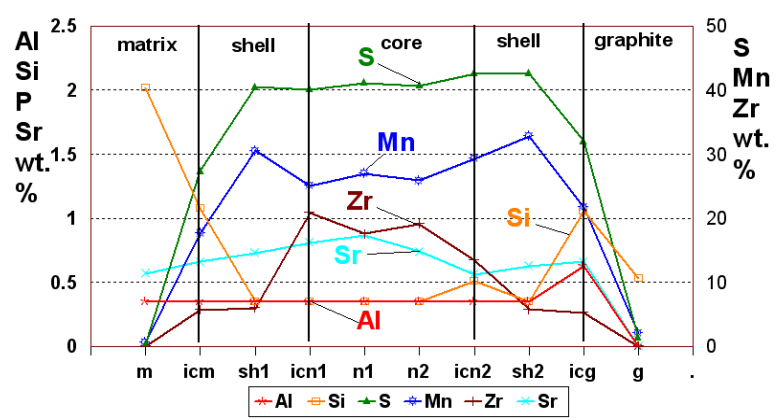

(d)

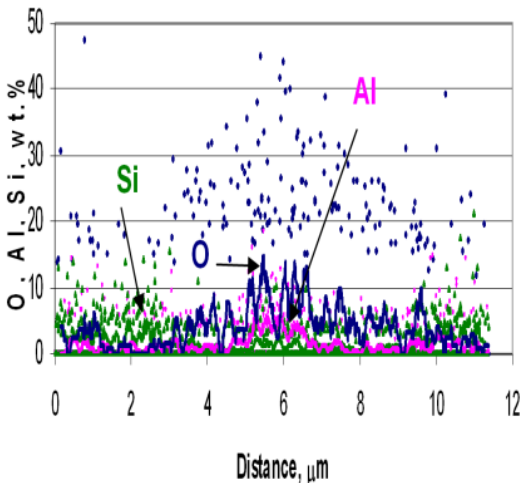

(f)

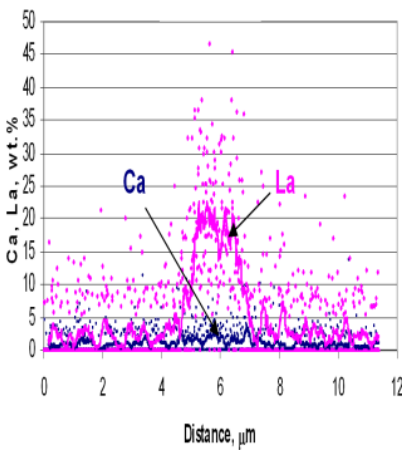

(g)

Fig. 6. Chemical analysis along cross-section of $(\mathrm{Mn}, \mathrm{X}) \mathrm{S}$ compound associated with graphite in grey irons: (a) $\mathrm{Ca}-\mathrm{FeSi}$; (b) Sr-FeSi; (c) $\mathrm{Al}+\mathrm{Sr}-\mathrm{FeSi}$; (d) $\mathrm{Zr}+\mathrm{SrFeSi}$; (e, f, g) La,Ca,Al-FeSi
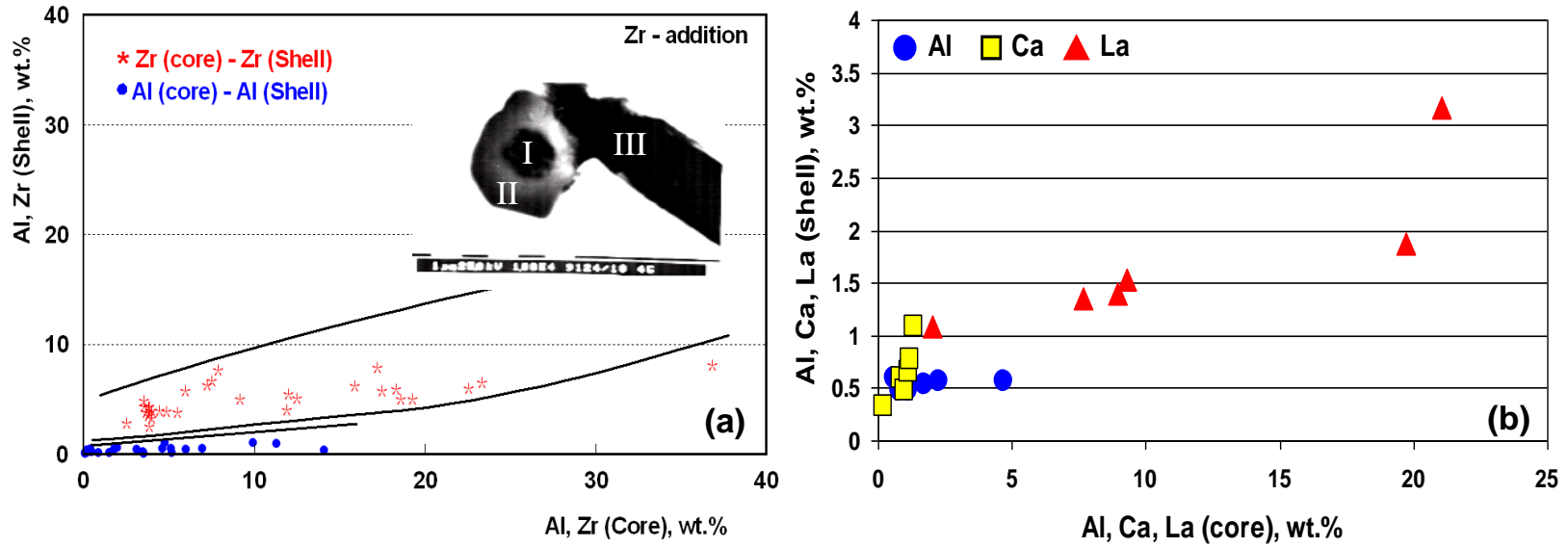

Fig. 7. Typical relationships of active elements in the first compound [I] [core / nucleus] and the second compound [II] [shell / body] of lamellar graphite [III] nucleants 
The particles associated with graphite have a lower $\mathrm{Mn} / \mathrm{S}$ ratio than the matrix embedded particles in all the examined specimens. In inoculated iron the (Mn,X)S compound is more complex and the crystallographic misfit between graphite and the compound is lower, such as ( $\mathrm{Mn}, \mathrm{Sr}) \mathrm{S}$ versus $\mathrm{MnS}$ (see Fig. 1). The factor $(\% \mathrm{Mn}) \times(\% \mathrm{~S})$ [14] appears to be a good control for the influence of these elements, as carbides, undercooled graphite or eutectic cells parameters (Fig. 8a).

$\mathrm{Al}$ appears to have a key role in graphite formation in grey cast iron at lower eutectic undercooling and chill tendency (Fig. 8b), especially for $(\% \mathrm{Mn}) \mathrm{x}(\% \mathrm{~S})$ less than 0.03 . Simultaneous $0.005-0.01 \% \mathrm{Al}$ and $(\% \mathrm{Mn}) \times(\% \mathrm{~S})=0.03-0.06$ conditions appear to be favourable for a structure without carbides and undercooled graphite. A double treatment (preconditioning with $\mathrm{Al}$ and/or $\mathrm{Zr}+$ inoculation) is recommended to raise the nucleation level [Programmes III, IV, V].

The complex inoculant system, including $\mathrm{La}-\mathrm{Ca}-\mathrm{Al}$ as active elements was very efficient in critical solidification conditions. Despite the relatively low carbon equivalent level [3.7\%CE], unfavourable contents of $\mathrm{Mn}, \mathrm{S}[(\% \mathrm{Mn}) \times(\% \mathrm{~S})=0.015]$ and $\mathrm{Al}(<0.005 \% \mathrm{Al})$, the $0.15 \mathrm{wt} \%$ addition of the complex inoculant led to a noticeable reduction of the eutectic undercooling, and, consequently, lowered the chill tendency, with a significantly higher eutectic cell count with improved graphite morphology [Programme VI].

The ability of the (S,O,Al,Ca)-FeSi alloy enhancer to generate sulphides increased the inoculating power for all inoculants $(\mathrm{Ca} / \mathrm{Ca}, \mathrm{Ba} / \mathrm{Ca}, \mathrm{RE}-\mathrm{FeSi}$ alloys $)$, with lower chill and higher Type-A graphite levels [Programmes VII, VIII]. Total inoculant consumption could be reduced by $50 \%$ when the inoculant enhancing alloy was utilized. Positive effects for enhancing inoculation with $\mathrm{S}, \mathrm{O}$ and oxy-sulphides forming elements alloy addition were also noted for ductile irons. [46]
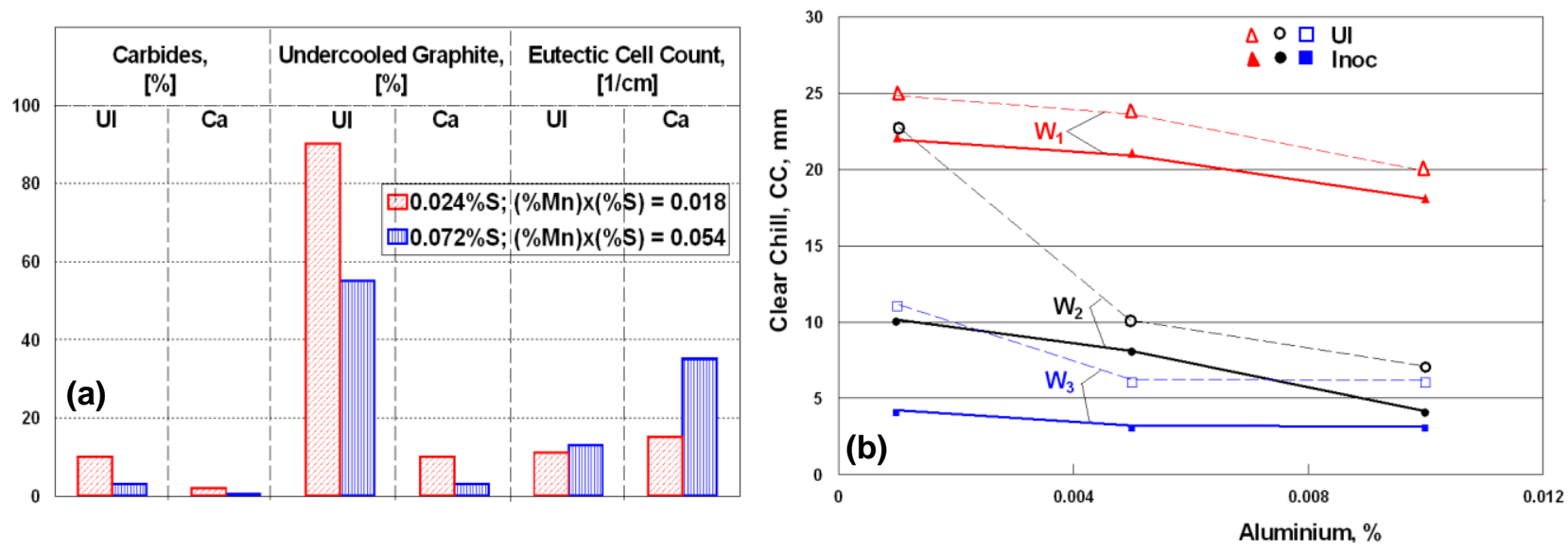

Fig. 8. Effects of $(\% \mathrm{Mn}) \times(\% \mathrm{~S})$ factor (a) and residual $\mathrm{Al}$ content (b) in grey cast iron

\section{Summary}

*Complex compounds act as nucleation sites in cast irons, in a general three-stage graphite formation, but with a different sequence for grey iron (GI) vs ductile iron (DI): (1) the first microcompound to form is an oxide/silicate (GI) vs sulphide (DI); (2) a second compound nucleated on the first one, as complex (Mn,X)S in GI vs complex silicates in DI; (3) graphite nucleation on the sides of the stage 2 compounds, which have low crystallographic misfit with graphite.

*Two major actions are necessary to sustain graphite formation in GI: (a) promote micro-oxides suitable to nucleate $\mathrm{MnS}$ compounds, with small sizing and highly compact; (b) promote the transition from simple $\mathrm{MnS}$ to complex $(\mathrm{Mn}, \mathrm{X}) \mathrm{S}$, improving their graphite nucleating capacity.

*O, S, Si, Mn, Al, Zr, Ca, Sr, La, Ti elements appear to have specific distribution patterns along a cross-section of these duplex structure $(\mathrm{Mn}, \mathrm{X}) \mathrm{S}$ compounds. Specific relationships between the content of some elements (Al, Si, $\mathrm{Zr}, \mathrm{Sr}, \mathrm{Ca}, \mathrm{La}$ ), in the first (oxide) and the second (sulphide) compounds were found, with possible inter-elements influence.

*Resulphurization to $(\% \mathrm{Mn}) \times(\% \mathrm{~S})=0.03-0.06$, preconditioning ( $\mathrm{Al}$ or/and $\mathrm{Zr}$ ), complex inoculants (including $\mathrm{Al}$, and/or $\mathrm{Zr}$ ), double treatments [preconditioning + inoculation; conventional 
inoculant + inoculant enhancer (which provides supplementary S, O and contains oxide-sulphide forming elements)] to sustain formation of active ( $\mathrm{Mn}, \mathrm{X}) \mathrm{S}$ compounds necessary for graphite formation, especially in critical casting conditions, such as low $\mathrm{S}$ content, high cooling rate etc.

\section{References}

[1] J. Zhou, China Foundry, 6(2) (2009) 52-69.

[2] I. Riposan, M. Chisamera, S. Stan, D. White, C. Hartung, C. $115^{\text {th }}$ AFS Casting Congr., Schaumburg, IL, USA, (2011), Panel Paper 11-131.

[3] C.R. Loper Jr, R.B. Gundlach, AFS Int. Inoculation Conf., Rosemont, IL, USA, (1998), Paper 1.

[4] C.R. Loper Jr, AFS Trans., 107 (1999) 523-528.

[5] R.J. Warrick, AFS Trans., 74 (1966) 722-733.

[6] R.L. Naro, J.F. Wallace, AFS Cast Met. Res. J., 6(4) (1970) 131-135.

[7] R.L. Naro, J.F. Wallace, AFS Trans., 78 (1970) 229-238.

[8] M.H. Jacobs, T.J. Law, D.A. Melford, M.J. Stowell, Metals Technol., 1(1) (1974) 490-500.

[9] M.H. Jacobs, T.J. Law, D.A. Melford, T.J. Stowell, Metals Technol. 3(1) (1976) 98-108.

[10] M.J. Lalich, J.R. Hitchings, AFS Trans., 84 (1976) 653-664.

[11] A. Sommerfeld, B. Tonn, Int. J. Cast Met. Res., 21(1-4) (2008) 23-26.

[12] A. Sommerfeld, B. Boettger, B. Tonn, Int. Foundry Res., 60 (2008) 2-5.

[13] A. Sommerfeld, B. Tonn, Int. J. Metalcasting, 3(4) (2009) 39-47.

[14] R. Gundlach, AFS Proceedings (2008) Paper 08-158.

[15] G. Alonso, D.M. Stefanescu, P. Larranaga, E. De la Fuente, R. Suarez, AFS Proc.(2016) 16-020

[16] D.M. Stefanescu, G. Alonso, P. Larrañaga, R. Suarez, Acta Materialia, 103 (2016) 103-114.

[17] D.M. Stefanescu, G. Alonso, P. Larrañaga, R. Suarez, Acta Materialia, 107 (2016) 102-126.

[18] T. Skaland, O. Grong, T. Grong, Met. Trans A, 24A (1993) 2321-2345.

[19] Y. Igarashi, S. Okada, Int. J. Cast Met. Res., 11 (1998) 83-88.

[20] J.A. Campbell, Met. Mater. Trans. B, 40(6) (2009) 786-801.

[21] G. Alonso, P. Larranaga, D.M. Stefanescu, E. De la Fuente, A. Natxiondo, R. Suarez, Int. J. Metalcasting, 11 (1) (2017) 14-26.

[22] J.K. Solberg, M.I. Onsoien, Mater. Sci. Technol., 17(10) (2001) 1238-1242.

[23] H. Nakae, Y. Igarashi, Mater. Trans., 43 (2002) 2826-2831.

[24] M. Chisamera, I. Riposan, S. Stan, T. Skaland, Proc. $64^{\text {th }}$ WFC, Paris, (2000), Paper No. 62.

[25] I. Riposan, M. Chisamera, S. Stan, T. Skaland, M. Onsoien, AFS Trans. 109 (2001)1151-1162.

[26] I. Riposan, M. Chisamera, S. Stan, T. Skaland, SPCI 7-Sci. Proc. Cast Iron Int. Conf., Barcelona, Spain, (2002), Int. J. Cast Metal Res. 16(1-3) (2003) 105-111.

[27] I. Riposan, M. Chisamera, S. Stan, T. Skaland, Proc. AFS Conf.“Cast Iron Inoculation”, AFS, Schaumburg, USA, (2005), 31-41.

[28] M. Chisamera, I. Riposan, S. Stan, T. Skaland, AFS Trans. 112 (2004) 867-877.

[29] I. Riposan, M. Chisamera, S. Stan, T. Skaland, Proc. $66^{\text {th }}$ WFC, Istanbul, Turkey, (2004) 775 790.

[30] I. Riposan, M. Chisamera, S. Stan, C. Ecob, G. Grasmo, Proc. $68^{\text {th }}$ WFC, India, (2008), Paper 53.

[31] I. Riposan, M. Chisamera, S. Stan, C. Ecob, D. White, Mater. Sci. Technol., 24(5) (2008) 578584.

[32] M. Chisamera, I. Riposan, S. Stan, D. White, G. Grasmo, Int. J. Cast Met. Res., 21(2008) 39

[33] I. Riposan, M. Chisamera, S. Stan, C. Ecob, D. Wilkinson, J. Mater.Eng. Perform., 18 (1), (2009) 83-87. 
[34] I. Riposan, M. Chisamera, S. Stan, G. Grasmo, C. Hartung, D. White, AFS Trans. 117 (2009), 423-434.

[35] M. Chisamera, S. Stan, I. Riposan, G. Costache, M. Barstow, AFS Trans. 116 (2008) 641-652.

[36] I. Riposan, M. Chisamera, S. Stan, E. Stefan, C. Hartung, Key Eng. Mater., l 457 (2011) 19-24.

[37] M. Chisamera, I. Riposan, S. Stan, C.B. Albu, R. L. Naro, AFS Trans., 115 (2007) 481-493.

[38] I. Riposan, I.C. Stefan, M. C. Firican, S.Stan, R. Naro, D. Williams, AFS Trans. 123 (2015) $227-242$.

[39] I. Riposan, M. Chisamera, S. Stan, P. Toboc, G. Grasmo, D. White, C. Ecob, C. Hartung, Proc. "Keith Millis" Symp. Las Vegas, NV, USA, (2008), 206-214; J. Mater. Eng. Perform., 20 (1), (2011) 57-64].

[40] M. Chisamera, I. Riposan, S. Stan, M. Barstow, Int. J. Cast Met. Res., 24(6) (2011) 370-377.

[41] I. Riposan, M. Chisamera, S. Stan, M. Barstow, China Foundry, 8(2) (2011) 228-234.

[42] S. Stan, M. Chisamera, I. Riposan, M. Barstow, J. Mater. Eng. Perform., 21 (2012)1793-1799.

[43] K. Oikawa, K. Ishide and T. Nishizawa, ISIJ Int., 37(4) (1997) 332-338.

[44] T. Sawai, M. Wakoh, Y. Ueshima et al, Proc. $6^{\text {th }}$ Int. Iron \& Steel Congr., Japan, (1990) 605611.

[45] M. Wakoh, T. Sawai and S. Mizoguchi: ISIJ Int., 1996, 36, (8), 1014-1021

[46] I. Riposan, M. Chisamera, S. Stan, V. Uta, I.C. Stefan, M.C. Firican, R.L. Naro, D.C. Williams. AFS Trans., 124 (2016) 247-266. 